\title{
Prevalence of Escherichia coli and Salmonella spp. in Captive Niligiri Langur (Trachypithecus johnii) in South India
}

\author{
P. Balaji ${ }^{*}$, K. Senthil Kumar ${ }^{1}$, K. Vijayarani ${ }^{2}$, S. Vairamuthu ${ }^{3}$, K. Karunakaran ${ }^{4}$, \\ K. Porteen ${ }^{5}$, Anjana Josy ${ }^{5}$ and S. J. Deepak ${ }^{5}$
}

${ }^{1}$ Department of Wildlife Science, Madras Veterinary College, Tamil Nadu Veterinary and Animal Sciences University, Madhavaram Milk Colony, Chennai-600051, Tamil Nadu, India ${ }^{2}$ Department of Animal Biotechnology, Madras Veterinary College, Tamil Nadu Veterinary and Animal Sciences University, Madhavaram Milk Colony, Chennai-600051, Tamilnadu, India

${ }^{3}$ Centralised Clinical Laboratory, Madras Veterinary College, Tamil Nadu Veterinary and Animal Sciences University, Madhavaram Milk Colony, Chennai-600051, Tamil Nadu, India

${ }^{4}$ Department of Animal Nutrition, Madras Veterinary College, Tamil Nadu Veterinary and Animal Sciences University, Madhavaram Milk Colony, Chennai-600051, Tamil Nadu, India

${ }^{5}$ Department of Veterinary Public Health and Epidemiology, Madras Veterinary College, Tamil Nadu Veterinary and Animal Sciences University, Madhavaram Milk Colony, Chennai-600051, Tamil Nadu, India

*Corresponding author

\section{A B S T R A C T}

The Niligiri Langur (Trachypithecus johnii) is a threatened black faced colobine which is endemic to Western Ghats in south India. The present study is designed to study the bacterial flora of gut from this non-human primate. The captive non-human

\section{Key words}

Zoological Park, Gut Microflora, Nilgiri Langur, Escherichia coli, Salmonella spp., Trachypithecus johnii

Article Info

Accepted:

22 May 2018

Available Online:

10 June 2018 primates usually suffer from gastrointestinal disturbances which often go unnoticed but they harbor variety bacterial flora in the gut. The Enterobactericeace such as $E$. coli, Shigella spp. and Salmonella spp. are some of the important bacterial species of gut flora. A total of 21 animals studied, of which 56 feacal swabs were collected from 18 animals from Arignar Anna Zoological Park (AAZP), Vandalur, Chennai and 8 feacal swabs from 3 animals from Sri Chamarajendra Zoological Park (SCZP), Mysore. The 64 fresh feacal samples were screened for prevalence of E. coli and Salmonella spp. by conventional cultural method and molecular techniques. The prevalence of $E$. coli was found to be 100 percent (n-64) by cultural and PCR assay whereas Salmonella was isolated from 67.18\% (43/64) viz., $37 / 56$ (66\%) in AAZP and $6 / 8(75 \%)$ in SCZP by cultural method and PCR. The isolates were further subjected to antibiotic sensitivity test and found that isolates are sensitive to gentamicin, azithromycin and ciprofloxacin but few isolates found resistant to amoxicillin and cefotaxime. The present study concludes that E. coli is highly prevalent compared to Salmonella in gut of Niligiri Langur. 


\section{Introduction}

Nilgiri Langur (Trachypithecus johnii) is a threatened black faced colobine that is endemic to Western Ghats in South India. Its range includes Kodagu in Karnataka, Kodayar Hills in Tamil Nadu and many other hilly areas in Kerala and Tamil Nadu. Nilgiri Langur has been classified as vulnerable under International Union for Conservation of Nature (IUCN) Redlist (ICUN, 2008). This endangered colobines would benefited from captive breeding programs, maintaining the healthy captive population of colobines can be difficult since they commonly suffer from morbidity and mortality due to gastrointestinal(GI) distress of unknown cause (Shelmidine et al., 2013). The gut microbiota is important in mammalian nutrition (Mackie, 2002). This gut microbiota help the animals to convert indigestible plant structural components such as cellulose to fatty acid chains which aids in animal energy meets (Flint et al., 2012). The colobines have sacculated foregut, which help in pregastric fermentation of food by gut microbiota (Davies and Oates, 1994).The normal inhabitant of non-human primate carry some of pathogenic organisms which includes, $E$. coli, Salmonella spp., Shigella spp., Klebsiella spp., Campylobacter spp. and more (Nizeyi et al., 2001). The presence of pathogenic bacteria in non-human primate has public health significance due to their close interaction with humans (Marshall, 1991). The primates carrying this organism may affect the health and the fatal infection from its excretion in faeces can carry out diseases to humans or as silent shredders (Mohan et al., 1973).

Escherichia coli are a Gram-negative bacteria and known gut commensal of animals, including non-human primates (NHPs). This diverse organism not only plays a role in the maintenance of gut health by helping to prevent the establishment of pathogenic bacteria in the gastrointestinal (GI) tract, but can also exist in a number of pathogenic forms (Jonathan et al., 2014). Salmonella spp. are gram negative bacteria that occur worldwide, inhabiting the intestinal tracts of many species including humans, nonhuman primates, birds, horses, pigs, dogs, cats, rats, mice, hamsters, guinea pigs and other species. There are more than 2000 recognized serotypes of Salmonella. Among these, $S$. typhimurium and $S$. enteritidis have been most commonly encountered in the gastrointestinal infections. The present study was taken to understand gut microbiota of Nilgiri Langur (Trachypithecus johnii) on an account of E. coli and Salmonella spp. from different captive facility in South India.

\section{Materials and Methods}

\section{Sample collection}

The samples were collected from the Arignar Anna Zoological Park, Vandalur, Chennai for isolation and identification of enteric bacterial micro flora in apparently healthy, captive Nilgiri Langur (Trachypithecus johnii) between June 2017 to January 2018. The study population includes 18 Nilgiri Langur held in captivity. The samples were fresh excreta from the Niligiri Langur in duplicates and collected by deeply inserting and rotating the sterile swab (Himedia, India) $15 \mathrm{~cm}$ long into freshly passed faeces. The samples were transported to the laboratory under refrigeration temperature within four hours. The samples were kept in refrigeration until further processing.

\section{Bacterial Isolation and Identification}

The bacterial isolation and identification of E.coli and Salmonella spp. bacteria by cultural method, the feacal samples were enriched aerobically by inoculating the feacal swab into 
nutrient broth for $E$. coli and Rappaport vassiliadis (RV) medium for Salmonella, incubated at $37^{\circ} \mathrm{C}$ overnight. The selective plating was done on Eosin Methylene Blue (EMB) Agar (Himedia) for E. coli and on Xylose Lysine Deoxycholate (XLD) Agar for Salmonella, incubated at $37^{\circ} \mathrm{C}, 24-36$ hours. The colony characteristic of E.coli was green metallic sheen on EMB and Salmonella spp. were slightly transparent halo with a black centre surrounded by pink-red zone on XLD. The standard biochemical tests performed for confirmation as per the Bergeys manual of determinative bacteriology (Cowan et al., 1993).

\section{DNA extraction}

The presumptive colonies of E.coli and Salmonella spp. grown on selective agar were used for DNA extraction. In brief, single colony from the selective media was suspended in $200 \mathrm{uL}$ of nuclease free water and washed twice. The DNA extraction was done using DNeasy Blood \& Tissue Kit $\left(\mathrm{QIAGEN}^{\mathrm{TM}}\right)$ as directed by the manufacturer.

\section{Polymerase Chain Reaction}

The E.coli was confirmed by PCR targeting uspA gene (Chenand Griffiths,1998) and the genus Salmonella spp. was confirmed by PCR targeting invA gene (Shanmugasamy et al., 2011). The primer sequence and cycling condition are given in (Table: 1). The PCR amplification was optimized using Eppendorf Master cycler personal as thermal cycler.

The $25 \mu \mathrm{L}$ PCR reaction mix was prepared using $12.5 \mu \mathrm{L}$ of Taq DNA polymerase $2 \mathrm{x}$ Master Mix RED (Ampilqon, India) which provides Tris- $\mathrm{HCl}$ ( $\mathrm{pH}$ 8.5), ammonium sulphate, $2 \mathrm{mM} \mathrm{MgCl}_{2}, 0.2 \%$ Tween 20, 0.4 $\mathrm{mM}$ (each) deoxyribonucleotide triphosphate (dATP, dCTP, dGTP, and dTTP), 2U of TaqDNA polymerase and $1 \mu \mathrm{l}$ of each oligonucleotide primer along with $3 \mu 1$ of template DNA. The PCR products were electrophoresed on $1.5 \%$ agarose gel prestained with ethidium bromide $(0.5 \mathrm{ug} / \mathrm{mL})$ and viewed under UV light using a UV Trans illuminator with the DNA bands sized by extrapolation based on mobility of $100 \mathrm{bp}$ DNA markers co-electrophoresed.

\section{Antibiotic sensitivity test}

Antimicrobial susceptibility test was performed by the disc diffusion method on Mueller-Hinton Agar (Himedia, Mumbai, India) using antimicrobial discs (Himedia, Mumbai, India) according to the instructions of Clinical and Laboratory Standards Institute (CLSI, 2015). Isolates were grown for 6 hours on nutrient broth (Himedia, Mumbai, India) and adjusted to $0.5 \mathrm{McFarland}$ using sterile physiological saline, swabbed onto the Mueller-Hinton medium (Himedia, Mumbai, India), and incubated with antimicrobial discs at $37^{\circ} \mathrm{C}$ for $18-24$ hours. A total of 5 antibiotic discs (Himedia, Mumbai, India) i.e Amoxicillin (AMX-10 mg), Gentamicin (GEN-10 mg), Azithromycin (AZM-30), Cefotaxime (CTX-5mg) and Ciprofloxacin (CIP-5 mg) were used. After incubation, the zone of inhibition was measured and compared with zone diameter interpretative chart to determine the sensitivity of the isolates to the respective antibiotics standards.

\section{Results and Discussion}

Prevalence of $E$. coli and Salmonella spp. by cultural method

Out of 64 samples collected from the captive Nilgiri Langur showed the prevalence of $E$. coli was 100 percent (64/64) from cultural and PCR assay in both the study areas whereas Salmonella isolated was 67.18 percent (43/64) by cultural method viz., 37/56 (66\%) in AAZP and 6/8 (75\%) in SCZP. 
E. coli was isolated and identified from the samples after cultivation on EMB agar. The prevalence of E. coli in the study was $100 \%$ (table: 2) the colony characteristic were yellow green with metallic sheen on agar plates and the staining characteristic were Gram negative, pink color, small rod shaped appearance arranged in single or paired short.

The biochemical test characters identified were Indole positive (+ve), Methyl red positive (+ve), VogesProskauer test negative (-ve), TSI test yellow butt and slant yellow(y/y), H2S negative (-ve), gas production positive $(+)$, citrate utilization test positive (+ve).

Salmonella spp. was isolated and identified from the samples culturing on XLD agar. The prevalence of Salmonella spp. in the study was 67.18percent (43/64) (table 2). The colony characteristic was red with black centre on agar plates and the staining characteristic were Gram negative, pink color, small rod shaped arranged singly or paired short. The biochemical test characters identified were Indole negative (-ve), Methyl red positive (+ve), VogesProskauer test negative (-ve), TSI test yellow butt and slant $\operatorname{red}(\mathrm{y} / \mathrm{r}), \mathrm{H} 2 \mathrm{~S}$ positive (+ve), gas production positive $(+)$, citrate utilization test positive (+ve).

Prevalence of $E$. coli and Salmonella spp. by PCR

E. coli was confirmed by pcr targeting uspA gene (universal stress protien) as described by (Chen and Griffiths, 1999). Similarly, Salmonella spp. was confirmed by invA gene (Shanmugasamy et al., 2011). The positive culture samples were screened by PCR to amplify the uspA for E. coli and invA gene for Salmonella spp., the amplified product found to be $884 \mathrm{bp}$ (Figure 1) for $u s p A$ and $284 \mathrm{bp}$ (figure 2) for invA gene fragment. The results shown in table 2 .

\section{Antibiotic sensitivity test}

The bacterial isolates of 43 Salmonella and 64 E. coli were subjected disk diffusion assay for further detection of antibiotic sensitivity test against antibiotics such as gentamicin, amoxicillin, azithromycin, cefotoxime and ciprofloxacin. The resistance pattern of $E$. coli and Salmonella spp. against different antibiotics given in table: 3 .

The isolation of E.coli and Salmonella spp. from apparently healthy Niligiri Langurs is first attempt to study microbiota from these captive Langurs. The prevalence of this organism has no doubt they are normal inhabitants of the gut microflora and some of them may be enteric pathogens. The presences of E. coli are indicators of potential hazardous infections of surrounding human communities (Bailey and Mansfield, 2010). Toxin producing Escherichia coli such as shiga toxigenic Escherechia coli (STEC) has potential to infect from mild diarrhoea to severe disease, in animals (Mansfield and Kemnitz, 2008). Colobine numbers in the wild are declining at a rapid rate with no signs of reprieve (IUCN, 2015), and while captivity offers colobines protection from external threats such as hunting and habitat destruction (Mittermeier et al., 2009), it is also associated with a distinct gut microbiota that may influence susceptibility to GI illness.

In this study, we aimed to determine the prevalence of E.coli and Salmonella in a captive population of Nilgiri Langur. The present study revealed the higher prevalence of E.coli (100\%) than Salmonella spp. $(67.18 \%)$, respectively.

Similar results were recorded in some studies, like the prevalence of $E$. coli is 100 percent (n33 ) and Salmonella paratyphi $\mathrm{A}$ is 87.9 percent (29/33) in non-human primates (NHPs) (okwari et al., 2014). 
Table.1 The primers sequences and cyclic conditions used in the present study

\begin{tabular}{|c|c|c|c|c|c|c|c|}
\hline Organism & GENE & \multicolumn{5}{|c|}{ SEQUENCE } & REFERRENCE \\
\hline \multirow[t]{4}{*}{ E. coli } & \multirow[t]{4}{*}{ uspA } & \multicolumn{5}{|c|}{$\begin{array}{l}\text { Forward 5-3-CCGATACGCTGCCAATCAGT } \\
\text { Reverse 5-3-ACGCAGACCGTAGGCCAGAT }\end{array}$} & \multirow[t]{2}{*}{$\begin{array}{l}\text { Chen and } \\
\text { Griffiths, } 1999\end{array}$} \\
\hline & & \multicolumn{5}{|c|}{ Cycling condition } & \\
\hline & & \multirow[t]{2}{*}{$\begin{array}{c}94^{\circ} \mathrm{C} \\
\text { for } 5 \\
\min \end{array}$} & $\begin{array}{l}94^{\circ} \mathrm{C} \text { for } 1 \\
\min \end{array}$ & $\begin{array}{l}57^{\circ} \mathrm{C} \text { for } 1 \\
\min \end{array}$ & $\begin{array}{l}72^{\circ} \mathrm{C} \text { for } \\
2 \mathrm{~min}\end{array}$ & \multirow[t]{2}{*}{$\begin{array}{l}72^{\circ} \mathrm{C} \text { for } \\
5 \mathrm{~min}\end{array}$} & \multirow[t]{2}{*}{$\begin{array}{l}\text { Product size } \\
\text { 884bp }\end{array}$} \\
\hline & & & \multicolumn{3}{|c|}{30 cycles } & & \\
\hline \multirow[t]{4}{*}{$\begin{array}{l}\text { Salmonella } \\
\text { spp. }\end{array}$} & \multirow[t]{4}{*}{$\operatorname{inv} A$} & \multicolumn{5}{|c|}{$\begin{array}{l}\text { Forward 5-3- GTGAAATTATCGCCACGTTCGGGCAA } \\
\text { Reverse 5-3-TCATCGCACCGTCAAAGGAACC. }\end{array}$} & \multirow[t]{2}{*}{$\begin{array}{l}\text { Shanmugasamy } \\
\text { et al., } 2011\end{array}$} \\
\hline & & \multicolumn{5}{|c|}{ Cycling condition } & \\
\hline & & \multirow[t]{2}{*}{$\begin{array}{l}94^{\circ} \mathrm{C} \text { for } \\
1 \mathrm{~min}\end{array}$} & $\begin{array}{l}94^{\circ} \mathrm{C} \text { for } 1 \\
\text { min }\end{array}$ & $\begin{array}{c}64^{\circ} \mathrm{C} \text { for } 30 \\
\text { sec }\end{array}$ & $\begin{array}{c}72^{\circ} \mathrm{C} \text { for } \\
30 \mathrm{sec}\end{array}$ & \multirow[t]{2}{*}{$\begin{array}{l}72^{\circ} \mathrm{C} \text { for } \\
7 \mathrm{~min} \text {. }\end{array}$} & \multirow[t]{2}{*}{$\begin{array}{l}\text { Product size } \\
284 \mathrm{bp}\end{array}$} \\
\hline & & & \multicolumn{3}{|c|}{35 cycles } & & \\
\hline
\end{tabular}

Table.2 Prevalence of E. coli and Salmonella spp. of captive Niligiri Langurat different facility

\begin{tabular}{|c|c|c|c|c|c|}
\hline SI & Sampling site & \multicolumn{2}{|c|}{ E.. Coli spp. } & \multicolumn{2}{c|}{ Salmonella spp. } \\
\hline $\mathbf{N o}$ & $+\mathbf{V e}$ & $\%$ & $+\mathbf{V e}$ & $\%$ \\
\hline $\mathbf{1}$ & $\begin{array}{c}\text { Arignar Anna Zoological Park } \\
\text { (Chennai) (n=56) }\end{array}$ & 56 & 100 & 37 & 66 \\
\hline $\mathbf{2}$ & $\begin{array}{c}\text { Sri Chamarajendra Zoological } \\
\text { Gardens (Mysore) (n=8) }\end{array}$ & 8 & 100 & 6 & 75 \\
\hline & Total & 64 & 100 & 43 & 67.18 \\
\hline
\end{tabular}

Table.3 Antibiogram for E. coli and Salmonella spp. isolated from captive Niligiri Langur

\begin{tabular}{|c|c|c|c|c|c|c|c|c|c|c|c|c|c|c|c|}
\hline \multirow[t]{2}{*}{ Organism } & \multicolumn{3}{|c|}{$\begin{array}{l}\text { Gentamicin } \\
(10 \mathrm{mg}) \\
\text { MIC: }<12- \\
>15 \mathrm{~mm}\end{array}$} & \multicolumn{3}{|c|}{$\begin{array}{l}\text { Amoxicillin } \\
\text { (10mg) } \\
\text { MIC: <19- } \\
>25 \mathrm{~mm}\end{array}$} & \multicolumn{3}{|c|}{$\begin{array}{l}\text { Cefotoxime } \\
(30 \mathrm{mg}) \\
\text { MIC: }<29- \\
>35 \mathrm{~mm}\end{array}$} & \multicolumn{3}{|c|}{$\begin{array}{l}\text { Azithromycin } \\
\text { (30mg) } \\
\text { MIC: <24->30 } \\
\text { mm }\end{array}$} & \multicolumn{3}{|c|}{$\begin{array}{l}\text { Ciprofloxacin } \\
\text { (5mg) } \\
\text { MIC: }<16->20 \\
\text { mm }\end{array}$} \\
\hline & $\mathrm{S}$ & I & $\mathrm{R}$ & $\mathrm{S}$ & I & $\mathrm{R}$ & $\mathrm{S}$ & I & $\mathrm{R}$ & $\mathrm{S}$ & I & $\mathrm{R}$ & $\mathrm{S}$ & I & $\mathrm{R}$ \\
\hline E. coli & 55 & 9 & - & - & 34 & 30 & - & 51 & 13 & 60 & 3 & - & 64 & - & - \\
\hline $\begin{array}{l}\text { Salmonella } \\
\text { spp. }\end{array}$ & 40 & 3 & - & - & 9 & 34 & - & 40 & 3 & 34 & 9 & - & 40 & 3 & - \\
\hline
\end{tabular}


Fig.1 PCR gel image of E. coli and Salmonella spp. isolated from captive Niligiri langur

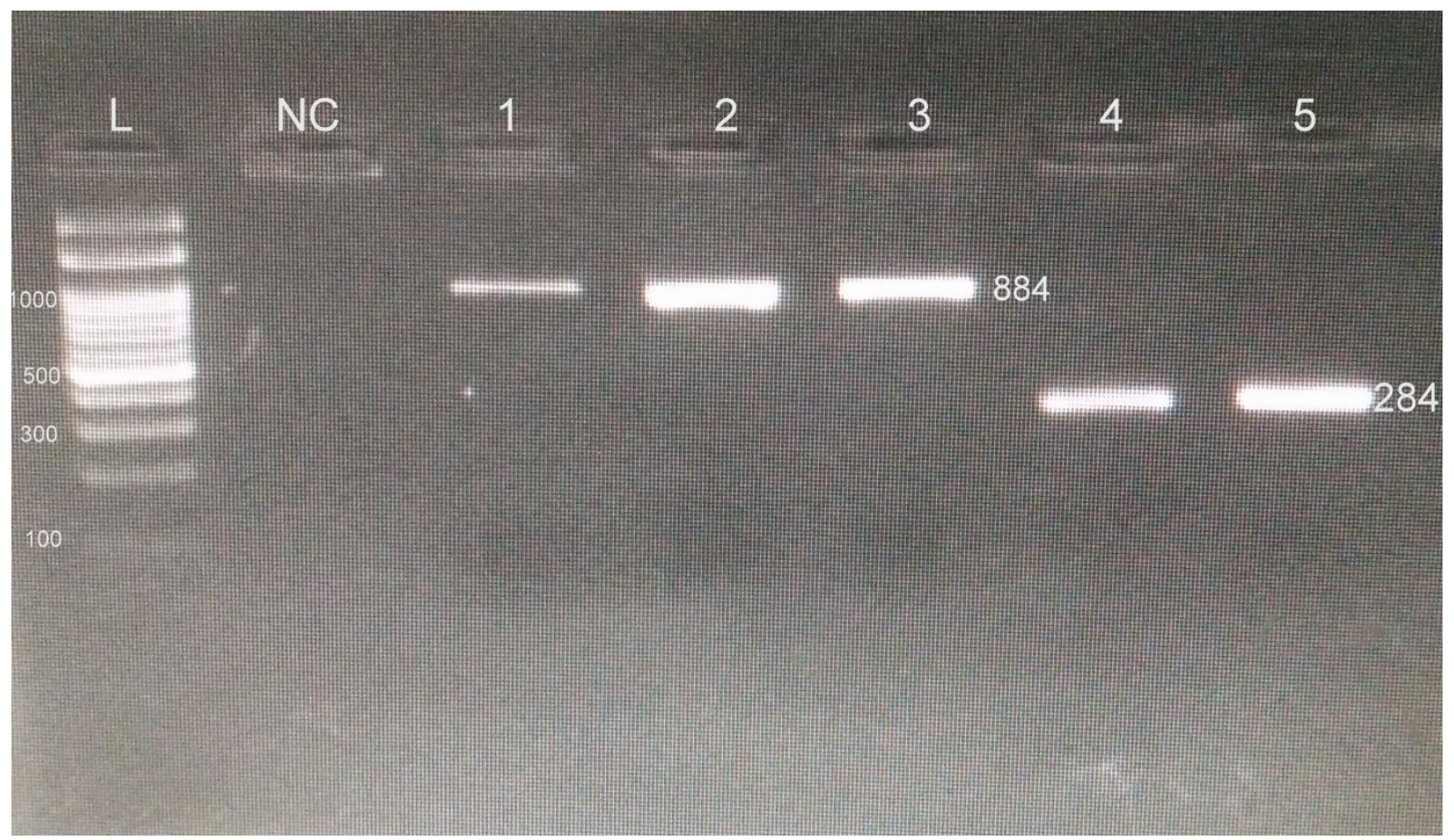

(L: Ladder, NC: Negative control, 1-3: E. coli, 4-5: Salmonella)

Enteropathogenic Escherichia coli (EPEC) infection was isolated in adult monkeys (rhesus macaques) (Sestak K et al., 2003). Isolation of Salmonella species been previously reported from Non-Human Primates (NHPs) (Robert et al., 1969). The mode of transmission is contaminated water, flies, infected dust; fruits and vegetables and human waste, they aid in transmission and may also contribute through animals diet. The prevalence in NHPs may thus indicate an anthropozoonotic transmission of these organisms. The prevalence of Salmonella paratyphi, Campylobacter and Yersinia, organisms are similar to findings of (Mikov, 1994).

The E. coli has high resistant against amoxicillin and cefotaxime whereas Salmonella spp. has resistant against amoxicillin and also showed intermediate resistance against cefotaxime. The isolates are sensitive against gentamicin, azithromycin and ciprofloxacin. The prevalence of antibiotic resistant E. coliin wild gorillas reported that ampicillin resistance followed by streptomycin resistance and tetracycline resistance in national park (Benavides et al., 2012).This tendency suggests the transmission of human-borne resistant bacteria to wildlife. In emperor tamarins showed highest prevalence of ampicillin resistance $(32.3 \%)$ and in white faced sakis (29.6\%) for E. coli (Jonathan et al., 2014).

This study shows the prevalence of E. coli and Salmonella spp. in healthy captive Niligiri Langur and it's reported for the first time. The prevalence of E. coli was 100 percent whereas Salmonella spp is 67.18 percent respectively. This current study may serve as guideline for future studies in the same species and other important gut microbiota. This study aided to know the gut microbiota in captive Nilgiri Langur supporting Asian colobine conservation 
efforts. The present data helps to formulate and treat animals with antimicrobials in captivity with GI disturbance.

\section{Acknowledgement}

The authors are thankful to the Dean Faculty Basic Sciences, Dean Madras Veterinary College, Tanuvas, authorities, Veterinarians of Arignar Anna Zoological Park (AAZP), Vandalur, Chennai and Sri Chamarajendra Zoological Park (SCZP), Mysore for providing all the necessary facilities to carry out the study.

\section{References}

Bailey, C. and Mansfield, K. 2010. Review paper: emerging and re-emerging infectious diseases of non-human primates in the laboratory setting. Vet. Pathol.47 (3):462-81.

Benavides JA, Godreuil S, Bodenham R, Ratiarison S, Devos C, Petretto MO, Raymond M, Escobar-Páramo P. 2012. No evidence for transmission of antibiotic-resistance Escherichia coli strains from humans to wild western lowland gorillas in Lope National Park, Gabon. Applied and Environmental Microbiology 78: 4281-4287.

Chen, J. and Griffiths, M.W. (1998) Detection of verotoxigenic $E$. coli using magnetic capture hybridization polymerase chain reaction. Applied Environmental Microbiology. 64, 147-152

Clinical and Laboratory Standards Institute (CLSI). 2015. Performance standards for antimicrobial susceptibility testing; Wayne, PA: NCCLS.

Cowan, S.T., Feltham, R.K.A., Steel. K.J. and Barrow, G.I. 1993. Cowan and Steel's manual for the identification of medical bacteria. $3^{\text {rd }}$ Edition, Cambridge university press.
Davies, A.G. and Oates, J.F. 1994. Colobine Monkeys- Their Ecology, Behavior and Evolution. Cambridge University Press, New York.

Flint, H.J., Scott, K.P., Duncan, S.H., Louis, P. and Forano, E. 2012. Microbial degradation of complex carbohydrates in the gut. Gut Microbes. 3(4): 289-306

IUCN 2015. The IUCN Red List of Threatened Species. Version 2015-4.

Jonathan, B. C., Jessica, L. D., Ava, M. T., Murphy, T. and Johnson, T. J. 2014. Longitudinal characterization of Escherichia coli in healthy captive nonhuman primates Frontiers in veterinary science. 1(24).

Mackie, R. 2002. Mutualistic fermentative digestion in the gastrointestinal tract: Diversity and evolution. Integr.Comp.Biol.42, 319-326.

Mansfield, K. G. K. G. and Kemnitz, J. W. J. W. 2008. Introduction: challenges in microbial quality control for non humanprimate. ILARJ, 49(2): 133-6.

Marshall, J. C. 1991. The ecology and immunology of the gasterointestinal tract in health and illness. J. Hosp. Infect. 19: 7-17.

Mikov, M.1994. The metabolism of drugs by the gut flora. Eur. J. Drug. Metab. Ph. 19:30-39.

Mittermeier, R.A., Wallis, J., Rylands, A.B., Ganzhorn, J.U., Oates, J.F., Williamson, E.A., Palacios, E., Heymann, E.W., Kierulff, M.C.M. and Yongcheng, L. 2009.Primates in Peril: The World's 25 Most Endangered Primates 2008-2010. IUCN/SSC Primate Specialist Group, Conservation International, Arlington, VA, USA.

Mohan, K., Pal, S.C., Ghosh, J.N., Chakravarty, A.K., Pattanayak, S. and Arya, S. C. 1973. Enteric infections in captive monkeys. Indian Journal of Medical Research. 61:363-8 
Nizeyi, J. B., Innocent, R.B., Erume, J., Kalema, G.R., Cranfield, M. R. and Graczyk, T. K. 2001. Campylobacteriosis, Salmonellosis and Shigellosis in free ranging human habituated mountain gorillas of Uganda. Journal of Wildlife Disease. 37:239244

Okwori, A. E. J., Nwankiti, O., Onaji, A. I., Aguoru, C. U., Ogbonna, B. I. O., Attah, A., Makut, M. D. and T. I. Adikwu. 2014. Bacterial Profiles Associated with Captive Non-Human Primates in Jos Zoo, Nigeria. International Journal of Tropical Disease \& Health. 4(4): 394-401.

Robert, C. G., Bessie, D. M. and Toshio, K. 1969. Enteric pathogens in monkeys. Journal of Bacteriology. 97: 1048-1055
Sestak, K., Merritt, C. K., Borda, J., Saylor, E., Schwamberger, S. R., Cogswell, F., Didier, E. S., Didier, P.J., Plauche, G., Bohm, R. P., Aye, P. P., Alexa, P., Ward, R. L. and Lackner, A. A. 2003. Infectious agent and immune response characteristics of chronic enterocolitis in captive rhesus macaques. Infec. Immun. 71:4079-4086

Shanmugasamy, M., Velayutham, T. and Rajeswar, J. 2011. invA gene specific PCR for detection of Salmonella from broilers. Veterinary World. 4: 562-564

Shelmidine, N., McAloose, D. and McCann, C., 2013. Survival patterns and mortality in the North American population of silvered leaf monkeys (Trachypithecus cristatus). Zoo Biol. 32, 177-188.

\section{How to cite this article:}

Balaji P., K. Senthil Kumar, K. Vijayarani, S. Vairamuthu, K. Karunakaran, K. Porteen, Anjana Josy and Deepak S. J. 2018. Prevalence of Escherichia coli and Salmonella spp. in Captive Niligiri Langur (Trachypithecus johnii) in South India. Int.J.Curr.Microbiol.App.Sci. 7(06): 3119-3126. doi: https://doi.org/10.20546/ijcmas.2018.706.366 